\title{
Global injustice, individual duties and non-ideal institutional circumstances
}

\author{
Injustiça global, deveres individuais $e$ \\ circunstâncias institucionais não ideais
}

Corinna Mieth*

\begin{abstract}
Resumo: As questões principais deste trabalho são: quais obrigações os ricos globais têm para com os muito pobres, considerando-se que a ordem institucional global é injusta? Há deveres para institucionalizar os direitos humanos sob tais circunstâncias institucionais não ideais? Quão fortes são estes deveres? Minha tese é que aquilo que torna deveres fortes ou fracos não é que eles sejam deveres positivos ou negativos, no sentido derivado da teoria da ação. Ao invés disto, a força de deveres individuais depende da sua referência a bens básicos e a sua especificação, o que depende em parte dos arranjos institucionais existentes, na medida em que envolvam viabilidade, determinidade, custo e eficiência.
\end{abstract}

Palavras-chave: injustiça global; deveres individuais; ordem institucional; direitos humanos; teoria da justiça.

\begin{abstract}
The main questions of this paper are: What duties towards the very poor do the global rich have given that the global institutional order is unjust? Are there duties to institutionalize rights under such non-ideal institutional circumstances? How strong are these duties? My thesis is that what makes duties strong or weak is not that they are positive or negative in the sense derived from the theory of action. Instead of this, the strength of individual duties depends on their reference to basic goods and their specification, which partly depends on existing institutional arrangements as far as feasibility, determinateness, costliness, and efficiency are concerned.
\end{abstract}

Keywords: global injustice; individual duties; institutional order; human rights; theory of justice.

\footnotetext{
* Ph.D. in Philosophy at Tübingen University, professor of Political Philosophy and Philosophy of Law at the University of Bochum, Germany. Research areas: positive duties, human rights, global justice, utopia. <corinna.mieth@rub.de>. Text presented at the Fifth International Symposium on Justice (Florianópolis, October, 3rd-7th 2011).
}

\begin{tabular}{|l|l|l|l|l|l|}
\hline Civitas & Porto Alegre & v. 12 & n. 1 & p. $47-69$ & jan.-abr. 2012 \\
\hline
\end{tabular}


The main question of this paper are: Which duties towards the very poor have the global rich given that the global institutional order is unjust? Are there duties to institutionalize human rights? How strong are these duties?

First, I will make some remarks about individual duties and the problem of their strength. I will defend the idea that reference to basic goods on the one hand and specification on the other determine the strength of a duty. If this is true, then duties corresponding to social human rights are strong only if there are adequate institutions in place.

Secondly, I will consider the idea that under ideal institutional circumstances the problem of world poverty would be solved by securing human rights. Non-ideal institutional circumstances are either circumstances of imperfect compliance with just institutions, or circumstances in which institutions are not in place, or circumstances under which human rights remain unfulfilled because of institutional failure. Here the most important question is how we can come from non-ideal institutional conditions to ideal institutional conditions. I will examine the revolutionary utopian strategy as well as the strategy of small steps introduced by Karl Popper and recently worked out by Amartya Sen.

Thirdly I will introduce two recent proposals concerning individual duties towards the very poor from Thomas Pogge and Elizabeth Ashford. While Pogge claims that we are contributing to and profiting from an unjust world order that causes poverty and have therefore compensating obligations of help and reform, Ashford claims that we have duties to create institutions that would solve the problem of world poverty. Both of them claim that these duties are strong and correspond to human rights. With regard to the question of a duty's strength, I will argue that it depends on two different factors: firstly, the importance of the good that is protected by a corresponding right, and secondly, the action's or omission's degree of determinateness as required by the duty. If this is right, then the duties referred to by Pogge and Ashford are not strong since they are underdetermined under given circumstances.

The last part of the paper will introduce feasibility, efficiency, costliness, and accountability for previous behaviour as additional criteria determining the strength of duties. The intention is to draw a more complex picture of what we consider as strong individual duties. What we will see is that the strength of individual duties partly depends on existing institutional arrangements as far as concerning feasibility, determinateness, costliness, and efficiency. Then again, the question is how institutional improvement is achievable. Here, it seems that people who push institutional improvement often do more than their duty on the one hand, or do not fulfill compliance duties with imperfect institutions on the other. 


\section{Some remarks about duties}

What is the problem with duties? In the recent debate about world poverty many authors especially point out that there is a problem with positive duties (Caney, Gilabert, Pauer-Studer, Pogge etc.). They seem less strong than negative duties, less determinate, have no corresponding rights and so on. ${ }^{1}$ Duties as such require that we restrict our options about what to do - and this is true for positive as well as negative duties. If positive duties require actions and negative duties require omissions, both restrict our behavioural choices. If I have the duty to save a child drowning in a shallow pond, I do not have the option to buy an ice-cream instead. If one accepts this as a starting point, the question becomes what constitutes legitimate restrictions of our options. Here, the first factor most plausibly seems to come from the theory of goods. If it makes sense to presuppose that all of us share basic needs, basic interests, transcendental interests, or rational interests concerning basic goods, it seems sensible to declare their protection a matter of rights and duties. The deal, as many have pointed out, is then that I have a right to life (not to be murdered or seriously injured) if I grant all others that right and this means that I accept the corresponding duty not to murder or seriously injure them (Gewirth, 1987).

Now, there has been a long discussion about the assumed asymmetry between positive and negative rights. The classical liberal conviction would be that negative rights are the only ones that can be legitimized. The underlying idea is that corresponding duties lead to a restriction of liberty that should be kept as tight as possible. The ideal of liberalism would then be, as Kant has once formulated it, that under just circumstances everybody would have what they deserve and that would be enough for everyone. ${ }^{2}$ If there would not be enough for everyone, this would not be due to injustice but to unlucky circumstances, to natural disasters, illnesses and so on. Under such circumstances, if someone was injured due to instances beyond human influence, what would still be

\footnotetext{
1 For a discussion of positive and negative duties see Pogge (2002; 2006), Gilabert (2005), Mieth $(2008 ; 2011)$.

2 "Es ist in der gantzen Welt nichts so heilig als das Recht anderer Menschen, dieses ist unantastbar, unverletzbar. [...] Wenn wir uns einen Menschen vorstellen, der nur nach Recht und nicht nach Gütigkeit handelt, so kann dieser Mensch sein Hertz immer vor jeden Menschen verschliessen, er kann gleichgültig seyn gegen sein elendes und jämmerliches Schicksal, wenn er aber nur gewissenhaft ist in Beobachtung der Pflichten gegen jedermann, wenn er nur jedes Menschen sein Recht, das der Regirer der Welt den Menschen gegeben hat, hält; wenn er keinem Menschen nicht das Geringst umsonst giebt, aber auch darin pünktlich ist, daß er ihm nichts entzieht; so handelt er recht, und wenn alle so handeln möchten, wenn alle keine Handlungen der Gütigkeit und der Liebe ausüben möchten, aber das Recht jedes Menschen unverletzt liessen, dann wäre kein Elend in der Welt, als nur ein solches Elend, was nicht aus der Verletzung des Rechts Anderer Fließt zE Krankheit, Unglücksfälle. Das größte und mehrste
} 
relevant were duties of humanity or benevolence. However, humanity or benevolence would not be a compensation for suffered injustices. In other words, if there still were basic goods missing under ideal circumstances of full compliance with negative duties, this would not be a question of justice. But, if we consider the question of rights and duties from the idea that the most important thing are the substances of the rights that should be protected, the borderline between positive and negative rights begins to shift.

One question is what should be protected, and the next question is how it should be protected. The first question leads us to a theory of basic goods or basic interests. As lots of defenders of positive rights have pointed out, wellbeing and subsistence are as important as security and freedom to lead a human life (cf. Shue, Gewirth, Pogge). The answer to the second question is more difficult. Henry Shue (2005) has pointed out that it is not rights but duties that are positive and negative. Both, security and subsistence lead to corresponding duties to avoid the violation of the substance of the right, as well as to duties to protect the substance of the rights, and at last to duties to help those who are deprived of the substance of the right. Now, what belongs to the realm of justice? Avoiding the destruction of already present subsistence? Providing for subsistence if anybody lacks the means to care for her own subsistence in the first place? These cases differ with respect to the notion of duties that one is willing to defend. Libertarians want to avoid as many restrictions of liberty as possible. The idea is that I am solely responsible for my own actions because that is what I can control. So, according to the libertarian view, it is forbidden to push a toddler into a shallow pond but not so concerning saving him if he drops in by himself. ${ }^{3}$

Elend der Menschen beruht mehr auf der Ungerechtigkeit der Menschen als auf dem Unglük. Da aber die Achtung des Rechts eine Folge der Grundsätze ist, die Menschen aber einen Mangel an Grundsätzen haben, so hat die Vorsicht einen andern Quell in uns gelegt, nämlich den Instinct der Gütigkeit, wodurch wir das ersetzen, was wir auf eine unrechtmässsige Art erlangt haben. Wir haben demnach einen Instinct zur Gütigkeit aber nicht zur Gerechtigkeit. Nach diesem Triebe erbarmen sich Menschen über andere und erzeigen Wohlthaten dem sie es vorhero entrisssen, Obgleich sie sich keiner Ungerechtigkeit bewust sind, das kommt daher, weil sie es nicht recht untersuchen. Man kann mit Antheil haben an der allgemeinen Ungerechtigkeit, wenn man auch keinem nach den bürgerlichen Gesetzen und Einrichtungen Unrecht thut. Wenn man nun einem Elenden eine Wohlthat erzeigt, so hat man ihm nichts umsonst gegeben, sondern man hat ihm das gegeben, was man ihm durch eine allgemeine Ungerechtigkeit hat entziehen helfen. Denn wenn keiner die Güter des Lebens nicht möchte mehr an sich ziehen wie der andere, so wären keine Reiche aber auch keine Armen, demnach sind selbst die Handlungen der Gütigkeit, Handlungen der Pflicht und Schuldigkeit, die aus dem Recht anderer entspringen." (Immanuel Kant, Vorlesung über Moralphilosophie, p. 282s, cf. Horn, 2007).

3 What is interesting concerning this example is that the English Common Law, Australia and most states of the US do not treat failure to render assistance in an emergency as a punishable deed whereas most European countries do. 
Many have attacked this view based on the insight that we consider it as a severe moral wrong not to help if an important good (the life of the child) is at stake that can be provided for easily. The point is that by accepting strong positive duties, what we have to do does not only depend on us and our previous actions but also on the world and the neediness of other people. Although I have not made any mistake, I must help other persons in need. While the minimalist libertarian view rejects the idea that we are responsible for evils that we have not caused ourselves, the maximalist utilitarian view holds that we should do anything we can to prevent evil from others. I think that both extreme views are mistaken. On the one hand, we know that there are strong positive duties, e.g. from parents towards their children. Now, the libertarian would accept this and say that such a duty comes from the parents' previous behaviour (begetting the child). Here we clearly see that the problem of the strength of a duty does not lie in its being positive or negative, understood as requiring an action or an omission. Positive duties, understood as duties that require a certain action, are not as such less determined or more costly than negative duties, understood as duties that require omission. So, what makes duties strong or weak is not that they are positive or negative in the sense derived from the theory of action.

We have to put the libertarian view into question, is when it claims that there is no strong duty to save an important good for someone to whom one has no previous relationship to. Against the libertarian point of view, I want to defend the idea that positive duties that do not go back to previous behaviour and, instead, refer to basic goods can nevertheless be strong. Against the maximalist utilitarian position, I defend the view that not from all threats to basic goods strong duties for anyone follow. J.O. Urmson (1958) has once formulated the insight that fulfilling a duty must lie within the capacity of ordinary men. If a duty is strong or basic, we mean that we could criticize someone who does not fulfill it for having made a serious mistake. And this is obviously not the case if each and every one of us had the strong duty to provide everyone else with basic goods. Either this does not lie within the capacity of ordinary men and women in the sense that it is not possible or it is infeasible to fulfill the duty - hence, there would be no duty since ought implies can ${ }^{4}$ - or to do our part, which might mean to do all we can in order to provide others with basic goods, might be too costly and therefore an illegitimate expectation. I will come back to this point in section four again. Moreover, and this will be my point in this section, what we should do in order to fulfill such a duty

\footnotetext{
${ }_{4}$ I will come back to this point in section four.
} 
might be too unspecified to identify a concrete duty-violation. On the one hand basic goods are the most important thing to be protected by imposing duties on others, but on the other hand it is not always clear what they have to do in order to protect basic goods of others. And if this is not clear it makes a big difference for the strength of the duty.

I suggest a reconstruction of the strength of duties according to two criteria. The first criterion is the significance of the good that is protected by the ensuing duty. This leads to a differentiation of the strength of duties according to the theory of goods that diverges from the differentiation of negative and positive duties according to the theory of action. Such a differentiation is very plausible in scenarios like Singer's drowning child case since it provides an explanation for the fact that most people would say that there is a strong duty to save someone from drowning if one can do this at almost no cost for oneself. The drowning-child scenario is analogous to the world poverty problem with respect to the goods involved on the side of the needy. The child's life is at stake and so is the life of the poor who might die from poverty-related diseases or hunger. But the two cases differ with respect to another morally relevant factor: in the drowning child case the positive duty to help is clearly specified while it is underdetermined in the poverty case. Furthermore, whereas the case of the drowning child refers to an unforeseeable individual problem, poverty refers to an institutional problem to secure social human rights. But without adequate institutions in place, duties corresponding to individual social rights remain underdetermined. I defend the idea that the strength of duties can depend on their specification so that specification can be considered as a second criterion concerning the strength of duties. From this we get the following picture: strong duties are duties which refer to basic goods and are specified; they include both negative and positive duties. However, there are specified duties not referring to basic goods (e.g. keeping promises), and these duties are weaker than those referring to basic goods. In case of conflict, the significance of the goods involved determines the priority of the duty. On the other hand, there are duties that refer to basic goods but are underdetermined. They seem to be weaker than duties that are determined but refer to minor goods (it seems that helping the poor today is not an excuse for breaking a promise).

If it is true that the strength of duties depends on their specification, different institutional arrangements would influence the strength of duties. As a German citizen, I have the duty to comply with the German social system by paying taxes. Since this duty is referring to basic goods and, at the same time, specified, it is also a strong duty. As the social human rights of compatriots 
are secured in this way this seems to be a human-rights-corresponding duty. Now the interesting question is the following one: what duties do individuals have if no institution is in place that could guarantee the protection of human rights? Here it seems plausible, as for example James Griffin (2009) proposes, to differentiate between primary duties that have the same content as human rights and secondary duties to promote human rights. But the problem we are left with in respect of social rights is that we do not even know what our primary duties would be without considering adequate social arrangements first. Therefore, I will take a look at ideal institutional circumstances in the next section.

\section{Ideal and non-ideal institutional circumstances}

What is relevant for our question about individual duties under non-ideal institutional circumstances is the following: what would individual duties be under ideal institutional circumstances? Where would this lead with respect to the protection of the substances of rights?

Libertarian institutions would secure that no individual kills, injures or steals from another. Under full compliance there might still be injuries or problems with subsistence that would result from natural circumstances instead of injustice. The same is true for the case that some individuals violate their duties but that the institution forces them to compensate for the damage they have inflicted on others.

If we directly measure the justice of a society with respect to the fulfillment of rights (the providence for their substances) accounting for to the goods available, we get quite a different picture. Alan Gewirth (1987) propounds that as long as someone is lacking basic goods and there are others that have more than enough they should transfer those goods and the needy person has a right to the goods in question. A society, then, is just if all goods at hand are distributed with respect to the fulfillment of negative and positive rights. The case that despite all duties being fulfilled, the substances of some rights still weren't provided could occur only if there was nothing left to redistribute.

On the other hand, a state of affairs where an adequate standard of living is realized might also be called ideal, but it need not be just since it could be combined with injustice understood as the lack of full compliance with just institutions.

There are two parameters of idealization: as far as the question of how people act is concerned, the matter is full compliance; as far as the question of state of affairs is concerned, the issue is whether people's endowment with basic goods is sufficient. 
The problem with the first parameter is that our question was how we could come to ideal institutional circumstances from a non-ideal world. The duty that leads us there cannot itself be a compliance duty. Maybe ideal scenarios provide an answer for the question: what would be an ideal scenario, given that all people would comply with the laws of the imagined society and given that further circumstances were good?-The question about what would be just given full compliance and good natural circumstances does not lead to an answer concerning our problem of individual duties under non-ideal institutional circumstances.

With regard to the question how to get from unjust circumstances to just institutional arrangements, Karl Popper has distinguished two methods: Utopianism and piecemeal engineering. He describes the Utopian approach as follows:

\begin{abstract}
Any rational action must have a certain aim. It is rational in the same degree as it pursues its aim consciously and consistently, and as it determines its means according to this end. To choose the end is therefore the first thing we have to do if we wish to act rationally; and we must be careful to determine our real or ultimate ends, from which we must distinguish clearly those intermediate or partial ends which actually are only means, or steps on the way, to the ultimate end. If we neglect this distinction, then we must also neglect to ask whether these partial ends are likely to promote the ultimate end, and accordingly, we must fail to act rationally. These principles, applied to the realm of political activity, demand that we must determine our ultimate political aim, or the Ideal State, before taking any practical action. Only when this ultimate aim is determined, in rough outline at least, only when we are in possession of something like a blueprint of the society at which we aim, only then can we begin to consider the best ways and means for its realization, and to draw up a plan for practical action. These are the necessary preliminaries of any practical political move that can be called rational, and especially of social engineering (Popper, 2003, p. 166s).
\end{abstract}

The two main problems of this approach are that the focus on the ideal either prohibits that anything at all is done if the circumstances are not favourable or that some revolutionary act is violently executed, and by doing so, more justice is paid for with unjust appliance of force and, therefore, with moral costs being too high. As opposed to utopianism, Popper proposes the method of piecemeal engineering, which starts with concrete solutions for concrete problems without planning a revolution of the whole system. It is not the ideal society, which is always difficult to defend against concurring 
models, that is taken as the starting point but concrete injustices most people agree should be abolished. ${ }^{5}$

I wish to outline another approach to social engineering, namely, that of piecemeal engineering. It is an approach which I think to be methodologically sound. The politician who adopts this method may or may not have a blueprint of society on his mind, he may or may not hope that mankind will one day realize an ideal state, and achieve happiness and perfection on earth. But he will be aware that perfection, if at all attainable, is far distant, and that every generation of men, and therefore also the living, have a claim; perhaps not so much a claim to be made happy, for there are no institutional means of making a man happy, but a claim not to be made unhappy, where it can be avoided. They have a claim to be given all possible help, if they suffer. The piecemeal engineer will, accordingly, adopt the method of searching for, and fighting against, the greatest and more urgent evils of society, rather than searching for, and fighting for, its greatest ultimate good. This difference is far from being merely verbal. In fact, it is most important. It is the difference between a reasonable method of improving the lot of man, and a method which, if really tried, may easily lead to an intolerable increase in human suffering. It is the difference between a method which can be applied at any moment, and a method whose advocacy may easily become a means of continually postponing action until a later date, when conditions are more favourable. And it is also the difference between the only method of improving matters which has so far been really successful, at any time, and in any place (Russia included, as will be seen), and a method which, wherever it has been tried, has led only to the use of violence in place of reason, and if not to its own abandonment, at any rate to that of its original blueprint (Popper, 2003, p. 168).

Furthermore, Popper claims that the method of small steps is more likely to be democratic than utopian engineering:

In favour of his method, the piecemeal engineer can claim that a systematic fight against suffering and injustice and war is more likely to be supported by the approval and agreement of a great

\footnotetext{
Amartya Sen is defending a comparable model in his recent book The idea of justice: He accuses the so called transcendental institutionalists of having no solutions for the problems of injustice and reforms under given non-ideal circumstances. "Perfect global justice through an impeccably just set of institutions, even if such a thing could be identified, would certainly demand a sovereign global state, and in the absence of such a state, questions of global justice appear to the transcendentalists to be unaddressable" (Sen, 2009, p. 25). The alternative, so called realization-focused comparison would aim at the abolition of manifest injustices. His question is: "What international reforms do we need to make the world a bit less unjust?" (ibid.).
} 
number of people than the fight for the establishment of some ideal. The existence of social evils, that is to say, of social conditions under which many men are suffering, can be comparatively well established. Those who suffer can judge for themselves, and the others can hardly deny that they would not like to change places. [...] But if it is easier to reach a reasonable agreement about existing evils and the means of combating them than it is about an ideal good and the means of its realization, then there is also more hope that by using the piecemeal method we may get over the very greatest practical difficulty of all reasonable political reform, namely, the use of reason, instead of passion and violence, in executing the program. There will be a possibility of reaching a reasonable compromise and therefore of achieving the improvement by democratic methods. [...] As opposed to that, the Utopian attempt to realize an ideal state, using a blueprint of society as a whole, is one which demands a strong centralized rule of a few, and which therefore is likely to lead to a dictatorship (Popper, 2003, p. 268s).

\section{Individual duties concerning world poverty: Pogge and Ashford}

As we have seen in the first section, a very straightforward answer to the question what duties we have towards the poor could be that if they have a human right to food and health services, everybody who could provide for these goods has a strong and direct duty to do so. For example Gewirth holds that there are positive human rights-corresponding individual positive duties. However, Onora O'Neill objects on the basis that this would be inefficient. If those rights need to be institutionally secured, there must be an institutional duty-allocation system. Hence, there are no individual positive duties directly corresponding to positive human rights (as Griffin implies in his thesis that there are primary duties and secondary duties to improve human rights development). Following Onora O'Neill, it seems that there are solely duties corresponding to social human rights if adequate institutions are in place first. Individual duties make no sense in this context since ought implies can: "Individuals cannot be obliged to resolve the problems of world hunger, or to grow wings and fly”. (O’Neill 2005, p. 251) But even if this were true, individuals might still be obliged to diminish poverty because they have the capability to lessen some of the suffering of the poor (as opposed to eradicate poverty or to "resolve" the problem). The question is, then, how strong this duty is. Here the classical Kantian answer would be that duties to diminish poverty are weak individual duties of benevolence. My point in section I has been that this duty is not weak because of its being positive. A positive duty 
like the duty to render assistance in an emergency such as Singer's drowning child case can be strong. The duty to diminish poverty is weak because it is underdetermined. There are some duties that refer to basic goods but remain underdetermined and are therefore weak.

Alternatively to duties corresponding directly individual human rights, many theorists have proposed that individuals have the duty to establish institutions that will protect social rights and allocate duties efficiently (Orend, 2002, p. 145; Ashford, 2006). They see O'Neills point that without institutional allocation of duties the problem of world poverty cannot be solved. Their point is, then, that there is an individual duty to create adequate institutions instead of or in addition to an individual duty to lessen the suffering of the poor directly. Elizabeth Ashford has recently pointed out the fact that both negative and positive rights confront us with an allocation problem concerning corresponding positive duties to protect. Ashford shows that "institutional structures are just as important in specifying and allocating many of the negative duties imposed by rights as the positive duties, so that the need for an institutional allocation of the corresponding duties does not distinguish positive rights to aid from negative rights not to be harmed" (Ashford, 2006, p. 221).

This is a point similar to the one we know from Henry Shue: Institutions must protect positive and negative rights via allocation of duties to avoid, to protect (e.g. of policemen) and to aid. In Ashford's picture not the existence of welfare rights is dependent on adequate institutional structures (like Onora O’Neill 1996 claims), rather the securing of the substance of welfare rights requires just global institutions. Therefore, under given nonideal circumstances, individual social human-rights-corresponding duties have the content of creating institutions that would secure these rights. If such institutions are not in place, or given institutions are unjust, individuals have a duty to institutionalization. Not the existence but the fulfillment of human rights is dependent on institutionalization. At first sight this seems very plausible.

But how exactly is a single individual able to fulfill this duty? What actions are required? Is electing the right party enough? What if the aim to establish just global institutions is not part of the program of any political party one could vote for? What is then required: the foundation of a new political party? Civil disobedience? Donations to NGOs? How much engagement can reasonably be expected? If we take a closer look at the duty to institutionalize human rights directed at an average individual, it is threatened by the problems of overdemandingness and inefficiency. Furthermore, as I have pointed out 
in the first section, the duty to institutionalize social human rights seems underdetermined in most cases: there are no clear options between which to decide. But if this is the case, no one can blame us for having acted in this or that concrete way or for not having done this or that.

Thomas Pogge's important proposal is that we must shift from an interactional understanding of human rights to an institutional one. He calls the interactional understanding "maximalist" and as such threatened by overdemandingness: "a human right to $\mathrm{X}$ gives you a moral claim against all others that they each do whatever is in their power to ensure that you have X" (Pogge, 2005, p. 64). It seems quite obvious that we can count Alan Gewirth as someone who has an interactional understanding of human rights. At first sight it looks as if Pogge would present us a more minimalistic and less demanding understanding of duties. He calls his own conception an institutional understanding of human rights as opposed to an interactional one.

But then he deduces individual human rights-corresponding (negative) duties from the institutional understanding "according to which a human right to $\mathrm{X}$ gives you a moral claim against all others that they not harm you by cooperating, without compensating protection and reform efforts, in imposing upon you an institutional order under which you lack secure access to $\mathrm{X}$ as part of a foreseeable and avoidable human rights deficit” (Pogge, 2005, p. 67).

This means that their human rights-standard is the criterion for the legitimacy of institutions. For individual duties this leads to a restriction in range and subject matter: Pogge claims that we only have to care for the human rights of those we share an institutional scheme with. What institutional scheme do we share with the very poor? Pogge's idea is that we, the citizens of the rich and mighty western democracies, are contributing to and profiting from the world order that shapes the expectations for the very poor in an unjust way. Therefore, we have harmed the poor and, hence, must make compensating efforts of protection and reform. At this point, there is a double relevance of democracy with regard to the origin and contend of our duties.

Democracy means that political power is authorized and controlled by the people over whom it is exercised, and this in such a way as to give these persons roughly equal political influence. Democracy involves voting - on political issues or on candidates for political offices - in accordance with the general idea of one-person-one-vote (Pogge, 2002, p. 146).

So, democracy is a means to human rights-fulfillment and is itself part of the claims that follow from human rights (first side of democracy). 
Duties to institutionalize human rights are also duties to democratization of authoritarian regimes. The opportunity of democratic participation is followed by the responsibility for the decisions that are met by the government. This is especially important as far as the citizens of western democracies are concerned since their governments shape the unjust global order in their name. Pogge writes:

We are asked to be concerned about avoidably unfulfilled human rights not simply insofar as they exist at all, but only insofar as they are produced by coercive social institutions in whose imposition we are involved. [...] The existing global institutional order is neither natural nor God-given, but shaped and upheld by the more powerful governments and by other actors they control (such as EU, NATO, UN, WTO, OECD, World Bank, and IMF). At least the more privileged and influential citizens of the more powerful and approximately democratic countries bear the a collective responsibility for their governments' role in designing and imposing this global order (Pogge, 2002, p. 172s).

Let us go a little more into detail about the institutional understanding. It entails the ideal that „human rights violations, to count as such, must be in some sense official, and [...] human rights thus protect persons only against violations from certain sources. Human rights can be violated by governments, certainly, and by government agencies and officials, by the general staff of an army at war, and probably also by the leaders of a guerrilla movement or of a large corporation - but not by a petty criminal or by a violent husband. We can capture this idea by conceiving it to be implicit in the concept of human rights that human-rights-postulates are addressed, in the first instance at least, to those who occupy positions of authority within a society (or other comparable social system)" (Pogge 2002, 57f.). But, and this is important for us here, within democracies, the accountability of human rights violations to officials goes back to those in whose name they act: "the language of human rights demands involves a demand for protection not only against official violations but, more broadly, against official disrespect, and it addresses this demand not only to officials, those whose violations of a relevant right would count as human-rights-violations, but also to those in whose name such officials are acting" (Pogge 2002, 58). In this sense, the accountability of human rights violations to individuals presupposes democratic structures.

A commitment to human rights involves one in recognizing that human persons with a past or potential future ability to engage 
in moral conversation and practice have certain basic needs and that these needs give rise to weighty moral demands. The object of each of these basic human needs is the object of a human right. Recognizing these basic needs as giving rise to human rights involves a commitment to oppose official disrespect of these needs on the part of one's own society (and other comparable social systems in which one is a participant) (Pogge, 2002, p. 58).

Here we are confronted with several degrees of institutional failure concerning human rights protection. Official disrespect of human rights goes back to governments and their agents and agencies. The idea is that this is the worst case since these are the actors that were especially required to protect these rights. So, they commit serious wrongs if they fail to secure human rights or even actively violate them. "Such wrongs do not merely deprive their victims of the objects of their rights but attack those very rights themselves; they do not merely subvert what is right, but the very idea of right and justice" (Pogge, 2002, p. 59).

All in all we can find three Versions of official disrespect of human rights: 6

- A Government does not order or authorize human rights violations and efficiently prevents them with respect to its own agencies and officials, but reserves the legal power to order violations itself.

- A Government is legally bound not to violate human rights but does nothing to ensure that its agencies and officials do abide by the prohibition. $^{7}$

- A Government is legally bound not to violate human rights and ensures that its agencies and officials do abide by the prohibition but fails to make violations illegal for other persons and associations under its jurisdiction (Officially tolerated private violence).

Now, depending upon how much influence our governments have on the global level in shaping the global order, they are violating human rights by not shaping a different, more human rights-friendly global order, and if our governments are democratic, we are responsible for their actions, which means that we are violating human rights, too.

\footnotetext{
6 "Governments may do so by issuing or maintaining unjust laws or orders that authorize or require human-rights violations or they may do so 'under color of law', that is, by perversely construing existing legislation as licensing human-rights violating policies" (Pogge, 2002, p. 59).

7 "Moral wrongs committed by an official fit the better under the label of 'human-rights violation' the more closely they are related to his job and the more tolerated or encouraged they are throughout officialdom" (Pogge, 2002, p. 59).
} 
The structure of the argument is as follows: The global order is responsible for local human-rights-unfulfillment. There are feasible alternatives to the present global order under which more human rights could be fulfilled (e.g. by institutional reform, by legally prohibiting the resource and borrowing privileges). The global order is unjust since these available options are not realized. The order is shaped by governments (and other actors). If we have democratically elected our government, we are also responsible for the unjust global order and its human-rights-violating consequences. Since we have a strong negative duty not to harm others by not contributing to injustice without compensating efforts of help and reform, we are violating human rights if we do not make these compensating efforts.

Still, it seems a little unfair to come to the conclusion that the average citizen of a western democracy is violating human rights of others since he has voted for, say, Angela Merkel. What alternatives would she have had? Would a vote for the SPD have brought a bigger advance for human rights development worldwide? This does not seem too plausible. At least the way we are involved in an unjust order is very far from the common forms of being, to a legally criticisable degree, involved into injustice. Let us have a brief look at two forms of criticisable forms of injustice:

Committing an injustice: This means directly harming another person. $\mathrm{He}$ is a means for my profiting from injustice (e.g. in German Law $\S 253$ StGB: extortion, $\S 240$ StGB: indecent assault, $\S 242$ StGB: theft, $\S 251$ StGB: holdup murder, $\S 211$ StGB: homicide) or the injustice is an end in itself (cf. self-administered justice, sex-murder) or the injustice is a result of a violation of another duty ( $\$ 229$ StGB: bodily injury caused by negligence, p.e. through driving under alcohol). Those infringements of the law require criminal prosecution. Furthermore they give rise to compensation, p.e. compensations for pain and suffering.)

Contributing to injustice: Here the contribution to the violation is indirect. This is the case if one does not press charges against someone planning a crime (cf. $§ 138$ StGB: Nicht-Anzeigen geplanter Straftaten; cf. $\S 258$ StGB: Strafvereitelung) or in the case of handling stolen goods ( $§ 259$ StGB). Those forms of contributing to injustice often go along with profiting from the injustice. Either they are themselves relevant to criminal law or they give rise to claims of restitutive justice.

However, one cannot say that the average citizens of rich and influential western democracies are committing injustice or contributing to it to such an extensive degree as just described (for the point that our contribution to injustice is too small to be assessed individually, cf. Shei 2005). But that would 
be necessary to demonstrate that we have strong duties to compensate for the injustices we have committed.

Where Pogge's institutional understanding of human rights seemed more minimalistic and less demanding than the individual one, it turns out to be as problematic as individual compensating duties that follow from it are concerned. These duties are as underdetermined as the duties that would directly follow from a conception of human-rights-corresponding positive duties either to provide others with basic goods or duties to establish institutions that would secure a duty allocation that would lead to an adequate providence with basic goods. If there is no clear metric concerning the amount of duty violation and the adequate amount of compensation, there is no advantage concerning demandingness as well. On the one hand, one could say that our contribution is so small that we have almost no compensation to make. Then this duty will not be very demanding but neither will it be very helpful. Contrariwise, the duty of compensation might be be very demanding since the world is very unjust, but it is not clear how we can avoid being involved in unjust structures. Since we would be back to problems of feasibility and efficiency discussed earlier, there would be no advantage compared to the maximalist understanding of human rights. Pogge's trump that we have strong duties only to compensate for evils we committed and not to help others where we did nothing wrong in the first place gets lost under non-ideal institutional circumstances that make it impossible to account individual contributions to an unjust world order.

Let us now reconsider Ashford's individual duties to institutionalize human rights. They refer to basic goods that are protected by human rights but they are underdetermined. Hence, if my account in section I is convincing, they are weak because of their indeterminateness. This makes them resemble classical duties of benevolence. But the concept of benevolence is misleading at this point. It comprises, for example in the Kantian picture, all duties that refer to the aim to further the well-being of others. This picture is misleading since there is a clear difference between the strength of the duty to improve Peter's well-being by inviting him for dinner (non-necessary good) and the duty to save a drowning child (necessary good). But if a duty that refers to a basic good is unspecified, it is still weak although it refers to a basic good.

There are three reactions to this diagnosis that we can take into account. First, one can deny that duties of institutionalization are underdetermined; second, one can deny that determinateness plays a role concerning the strength of these duties - I will reject these strategies in the last part of the paper (section four) -third, we can accept the analysis. The question is, then, whether we can gain something by shifting from duties to responsibilities. Maybe the notion 
of responsibility is more adequate to describe the phenomenon concerning the weakness of human-rights-corresponding duties under non-ideal circumstances than the notion of duty. If we shift from duties to responsibilities (as it is common in the current debate), this might have the advantage that we can shift from a moral concept to a strategic one. Even if duties of institutionalization are underdetermined in general, it may be possible to assign responsibilities to improve human rights-standards according to certain criteria. Instead of claiming abstract duties, the task consists in showing which responsibilities can be assigned to us according to our range of action. These responsibilities will be specific and may be considered as duties according to their degree of specification. Under non-ideal institutional circumstances, on a pragmatic level, the strength of duties depends on specific possible assignations of responsibilities. For the individual, this requires her to critically review her specific range of action and determine which actions or omissions lead to human rights improvement or deterioration.

\section{The diagnosis of injustice and the relevance of feasible alternatives}

If we do consider world poverty as a problem of injustice, this implies that someone is responsible for it. We can then also hope that the same entity that is responsible for its occurrence or persistence is responsible for its removal and able to do so. In order to understand the problems and implications of the positions just discussed better, let us differentiate between the following cases that differ with respect to feasibility, understood as the possibility of actors to change a bad situation.

\section{Scenario A: There exists no injustice, but unfortunate natural circumstances.}

Imagine ten people a hundred years ago standing around an eleventh person who is dying from angina, that he caught during the cold winter. None of them has the means to save him (since antibiotics have not been discovered yet). We would not say that any one of them committed an injustice by not saving him though having tried the best they could.

To save the man is infeasible in the sense that it was impossible to save him since the only means to save him were principally out of reach.

\section{Scenario B: Injustice or lack of humanity?}

Imagine ten persons standing around the eleventh man with angina in the 1980ies. 
B1: None of them has access to antibiotics, nor money to buy some. The situation would be comparable to A: it is infeasible for the others to save the person.

B2: One of them, a pharmacologist, has the antibiotics. However, the man with angina has no money, and the pharmacologist refuses to give him the pharmaceutics for free. The laws of the society in question protect property rights and forbid stealing the medication. The other nine could steal the medication and save the man. Now, while it is feasible for all of them to save the man, the question is whether they have a duty to do so.

B3: The Society could establish public health insurance, into which all eleven persons would have to pay money. The insurance, then, would pay for the antibiotics of the ill person, while all of them would then have the duty to comply with public health laws of the society. Whether this alternative is feasible seems to depend on further factors, for example whether there are institutions that could efficiently enforce this system?

What the scenarios should have demonstrated is the following. First, if it is impossible to save someone, there is no duty to do so. That is the well-known "ought implies can". There is no guilt, no injustice, and no moral problem, if it was beyond human reach to change the situation for the better: there simply was no alternative option. Infeasibility in a strict sense denies the existence of a duty. Second, even if it were possible, which means feasible in the sense that there is an alternative option (to give the medication for free/to steal the medication), this does not directly lead to the conclusion that there is an individual duty to do so regardless of the circumstances. In this case, other morally relevant factors play a role as well, especially demandingness (Can we expect the pharmacologist to give the medication for free? Can we expect the man who steals the medication to accept severe punishment for stealing?). Third, since the second situation is already normatively determined (stealing is forbidden, giving medication to the poor is not somehow institutionally arranged), the question is whether we need an alternative institutional arrangement under which there would be no conflict between anti-stealing laws and individual duties to save lives. If such an arrangement is infeasible, the question reoccurs whether we face an injustice or just unlucky circumstances. If the arrangement, on the other hand, is feasible, the question reoccurs whether the alternative is justifiable: Are the duties that would be imposed under it too demanding? Would the introduction of the new arrangement via enforcement lead to other injustices? Would the introduction of the new system be effective? 
Let us now, for the sake of the argument, assume that a) from B1 does not follow a duty to save the man since this would be overburdening under given institutional circumstances (actions to save the man might be supererogatory or legally excusable but not required), and b) there is a feasible institutional alternative, but this alternative is not in place. What does follow for the duties of the ten men? As we have seen, Ashford's answer is that they have a duty to institutionalize the adequate health care system. Let us now ask again: is this feasible?

B4: The situation harks back to B2, but now B3, as an option, is known by all eleven men. Now, how can they institutionalize the health care system? B4.1: There is a political party that has B3 on the agenda. In this case, do they have a duty to vote for that party? (Let us, for the sake of the argument, assume that there are only two parties with only two programs: pro and con public health care.) B4.2: There is no political party that has $\mathrm{B} 3$ on its agenda. Are we now back to $\mathrm{B} 1$, or do the men have the duty to found a new party?

What B4 shows us is that existence, strength and content of duties can depend on circumstances that we cannot fully control. Even if we assume that there is a party that has the public health care program on its agenda, as in B4.1, help for the ill man will come too late. The individual problem and the structural problem differ. The man in question cannot be saved by the fulfillment of the duty to bring better institutions into place. In our example, it may seem right to vote for the party that has health care on its agenda, but this is for the sake of fulfilling the duty to support (or establish) just institutions, not for the sake of saving the man. One might say that the case of the man shows us that we need better institutions, and that we wouldn't have realized why this is important without this experience. But even so, this still would not help that man. The duty to vote for the health insurance party would follow directly from a duty to act politically responsible whether or not one had contact to the ill man. On the other hand, if there were no possibility to create better institutions in this respect, or to at least contribute to doing so, as in B4.2, there seems to be no duty to do so, as is the case in A and in B1. And this case is comparable to the average western citizen's options with respect to the world-poverty-problem.

Still, under the premise that there is no global health care system in place, let us go back to B2 and the question whether the pharmacologist should give the medication for free or the other men should steal it. Under non-ideal institutional circumstances, the action of the pharmacologist would be supererogatory as he has no legal duty to give the antibiotics for free, 
and his act would also be supererogatory if he would do more than other pharmacologists in a similar situation.

From the utilitarian point of view that Peter Unger (1996) has pushed, we are allowed to beg, steal and borrow in order to save lives. Nevertheless, under the institutional arrangement assumed in B2, the men would face severe costs for breaking the law. Now we could consider their stealing the medication an act of civil disobedience. Since the institution is unjust compared to the feasible alternative B3, they are morally allowed to steal the medication although this means breaking the law in the unjust society. But even if this were true, it would not be clear whether by doing this the men would fulfill their duty to create better institutions. Some duties do not exist because the required action is not feasible (cf. case A). And even if there is a feasible action, this might not lead to the success the duty aims at (cf. case B4.1). Furthermore, it could be feasible to help the man by stealing but this might be too costly for the one who would be punished for this action. Likewise, it is not clear whether other actions that would not directly help the man but have some political significance, like telling all others that the given institutional health care system is unjust, could count as duties to help the man (since it might be inefficient) or as duties to institutionalize rights (since it might be inefficient, too). It seems that the strength of duties can indeed be assessed by the first criterion, the reference to basic goods, and the second criterion, specification. If we interpret specification via feasibility, costs, and efficiency, we get a more complex picture. There might be options for actions that are specified but inefficient or too costly so that it would not be adequate to speak of a duty either.

To conclude I would say that our world is not assessable in terms of compensating obligations deduced from ideal conception of justice since there is too much contingency. Nor is it assessable in terms of duties to institutionalize human rights under very unfavourable institutional conditions. At least this is so if we employ a notion of a strong duty as it was proposed in section I. We could, of course, change this notion and characterize a duty as strong based solely on its reference to basic goods, without regard for its degree of determinateness. But neither can I see how this fits with our considered moral judgements nor does it seem to be in accord with our practice. Now of course our question was how we could change the world for the better with respect to the institutional improvement of human rights standards.

First, it seems clear that under given non-ideal institutional circumstances duties of compliance with ideally just institutions are not the same duties as the 
duties to create these institutions. We could for example say that the costs that we would have under ideal conditions are also justified with respect to what we could reasonably be expected to do under given non-ideal circumstances. (If I would have to pay, say, 100 Euro taxes under a just global institutional arrangement, I could be expected to give these 100 Euro to, say, Amnesty International, in order to improve institutional human rights enforcement.) As the examples above were meant to show, this would still not be some feasible act of institutionalizing human rights. We could now say that a contribution to human-rights-improvement would be a more precise formulation of the duty in question, but then we are back to the problem that this contribution is not very specified with regard to what costs it may legitimately entail or with regard to what exactly it affords.

Second, these problems, as I take it, arise from the fact that a useful notion of a strong duty, like for example Urmson proposed, is created for clear interactional and institutional contexts. Institutional changes and social movements cannot usefully be described as hark back to people realizing what their duties to institutionalize human rights were. It is more probable that they realized that some injustices, such as slavery, were intolerable. Some of those who were convinced of this fact did more than their duty to fight for the abolition of slavery. They risked their lives for their political convictions, going way beyond any notion of strong duties described above. Even if it was not clear whether the actions that led to the abolition of slavery would be successful, people were convinced that they were right. The more people join a social movement or give an example of moral courage, the more will others realize what their options are and institutional arrangements will change.

Third, it seems that, with regard to the two methods compared in section II, utopianism is indeed inadequate. At least the examples presented above seem to suggest that trying to derive strong individual duties under non-ideal circumstances from an idea of ideal social arrangements leads nowhere. What about a duty to remove injustice, then? To fulfill this duty would, as the examples indicate, also be infeasible. We might have more chances of getting somewhere if we instead employ the idea of piecemeal engineering. However, Popper develops this method as an experimental one and not as one from which clear duties follow. If it is clear that a situation is unjust, it might nevertheless not be clear what to do. With respect to the examples above, one could, amongst other things, steal the medication, vote for another party, tell everyone how unjust the health system is, shout at the pharmacist, write a letter to some influential politician, or join a demonstration. I do not think that there 
is a strong duty to do any of these things, but on the other hand, these things might belong to a process piecemeal engineered social change. Some of them might be in vain with respect to what happens to the ill man, but they might still have some symbolic political power and change things for the better in the future.

\section{References}

ASHFORD, Elizabeth. The inadequacy of our traditional conception of the duties imposed by human rights. Canadian Journal of Law and Jurisprudence, v. 19, n. 2, p. 217-35, 2006.

GEWIRTH, Alan. Private philanthropy and positive rights. Social Philosophy \& Policy, v. 4, n. 2, p. 55-78, 1987.

GILABERT, Pablo. The duty to eradicate global poverty: positive or negative? Ethical Theory and Moral Practice, v. 7, n. 5, p. 537-550, 2005.

GRIFFIN, James. On human rights. Oxford: Clarendon Press, 2009.

HORN, Christoph. The concept of love in Kant's virtue ethics. In: BETZLER, M. (org.). Kant's ethics of virtue. Berlin: de Gruyter, 2007. p. 147-174.

KUPER, Andrew (org.). Global responsibilities: who must deliver on human rights? London: Routledge, 2005.

MIETH, Corinna. World poverty as a problem of justice? Ethical theory and moral practice, v. 11, n. 1, p. 15-36, 2008.

O'NEILL, Onora. Towards justice and virtue. Cambridge: Cambridge University Press, 1996.

Global justice: whose obligations? In: CHATTERJEE, Deen K. The ethics of assistance: morality and the distant needy. 2. ed. Cambridge: Cambridge University Press, 2005. p. 242-259.

OREND, Brian. Human rights. Concept and context. Ontario: Broadview Press, 2002.

POPPER, Karl. The open society and its enemies. v. 1: The spell of Plato. London: Routledge, 2003.

POGGE, Thomas. World poverty and human rights. Cambridge: Polity, 2002.

. Severe poverty as a violation of negative duties (reply to the critics). Ethics and International Affairs, v. 19, n. 1, p. 55-83, Spring 2005.

Globale Armut: Erklärung und Verantwortung. In: KOLLER, P. (org.). Die globale Frage. Empirische Befunde und ethische Herausforderungen. Wien: Passagen Verlag, 2006. p. 95-130.

SEN, Amartya. The idea of justice, London: Belknap Press, 2009.

SHEI, Ser-Min. World poverty and moral responsibility. In: FOLLESDAL, A.; POGGE, Th. (orgs.). Real world justice: grounds, principles, human rights and social institutions. Dordrecht: Springer, 2005. p. 139-155. 
SHUE, Henry. Basic rights: subsistence, affluence and US foreign policy. 2. ed. Princeton: Princeton University Press, 2005.

UNGER, Peter. Living high and letting die: our illusion of innocence. Oxford: Oxford University Press, 1996.

URMSON, J.O. Saints and heroes. In: MELDEN, A. (org.). Essays in moral philosophy. Seattle: University of Washington Press, 1958. p. 198-216.

Recebido em: 21.11.2011

Aprovado em: 29.12.2011 